\title{
Ongrowing and enhancement of n-3 HUFA profile in adult Artemia: Short vs long-time enrichment
}

\author{
Miquel Planas ${ }^{a}{ }^{*}$, Catarina Silva ${ }^{\mathrm{b}}$, Patricia Quintas ${ }^{\mathrm{a}}$, Alexandro Chamorro a, Sonia \\ Piñero ${ }^{a}$ \\ a Instituto de Investigaciones Marinas (CSIC), Eduardo Cabello 6, 36208 Vigo, Spain \\ b Present address: Metapopulation Research Centre, Department of Biosciences, University of Helsinki, \\ Finland \\ * Author for correspondence: Phone: + 34 986214457; Fax: +34 986292762; e-mail: mplanas@iim.csic.es
}

\section{Abstract}

The use of adult Artemia is uncommon in aquaculture and limited to feeding adults of species not accepting inert diets. The aim of the present study was the development of a standardized technique for adult Artemia production in small volumes (25-100 L) and the assessment of ongrowing and enrichment diets for enhancement of n-3 HUFA content. We firstly assessed the effect of initial nauplii density $\left(1,2\right.$, and 3 nauplii $\left.\mathrm{mL}^{-1}\right)$ and food dose $(x 1$, x2, and x3 quantities of mixed Tisochrysis lutea, Spirulina and Prolon) for production of Artemia. Intermediate nauplii densities and food doses yielded the best overall results (44-46\% survival; 5.6-5.9 mm length; 365-456 $\mu$ g Artemia-1). Secondly, four diets (mixtures of Tisochrysis lutea, Phaeodactylum tricornutum, Spirulina sp., Prolon and Red Pepper) were tested for ongrowing. Also, ten short-time enrichments (STE; $30 \mathrm{~h}$ ) and a long-time enrichment (LTE; 9 days) were also assayed for n-3 HUFA enhancement. The improvement in $n-3$ HUFA was rather limited in STE. However, LTE on a mixture of $P$. tricornutum, Prolon and Red Pepper (regardless of further STE) in ongrowing Artemia yielded the highest contents in total fatty acids and in 20:4n-6 20:5n-3, 22:5n-3 and 22:6n-3. The quality of LTE Artemia was based on an equilibrated dietary source of protein (Spirulina), 20:5n-3 (P. tricornutum) and 22:6n-3 (Red Pepper). STE Artemia had a quality similar or even higher than that of captured zooplankton and its use in our laboratory for the feeding of seahorses significantly enhanced breeding and newborn quality.

Abbreviations: AA - arachidonic acid; DHA - docosahexaenoic acid; EFA - essential fatty acid; EPA - eicosapentaenoic acid; FA - fatty acid; HUFA - highly unsaturated fatty acids; LTE - long-time enrichment; PCA - principal component analysis; STE - short-time enrichment

Keywords: Artemia, ongrowing, microalgae, enrichment, fatty acids, HUFA, seahorse.

\section{Acknowledgements}

This study has received funding by the SPANISH MINISTRY OF SCIENCE AND TECHNOLOGY (Proyecto Hippocampus; CGL2005-05927-C03-01) and the REGIONAL GOVERNMENT OF GALICIA (XUNTA DE GALICIA; PGIDIT06PXIC402106PN). P. Quintas was supported by a postdoctoral JAE-Doc/JAE-PhD contract from the Spanish Council for Scientific Research (CSIC), co-financed by the European Social Fund, and C. Silva was granted an Erasmus scholarship (Erasmus 29154-IC-1-2007-1-PT-ERASMUS-EUC-1). We are grateful to Bridie Kennerley, Alexandra Mundy (language review), Lourdes Nieto (preparation of microalgae) and, María Jesús González and Isabel Medina (fatty acids analyses of microalgae). 


\section{Introduction}

Early developmental stages of Artemia are commonly used for feeding of various larval organisms, including fish and crustaceans. Most developed juveniles and adults in production systems successfully accept inert diets or formulated feed and hence ongrownn adult Artemia is rarely used. However, for some organisms such as seahorses, require a supply of live or frozen zooplankton throughout the whole rearing system (Olivotto et al., 2011).

The nutritional quality of Artemia is limited (Léger et al., 1986), particularly in regards to n-3 HUFA. This is a concern as n-3 HUFA are essential to most marine vertebrates (Sargent et al., 1995, 2002). The natural diet of marine fish and crustaceans is rich in n-3 HUFA, commonly reflected in the fatty acids profile of eggs (Tocher and Sargent, 1984; Bruce et al., 1999; Tocher, 2003). Providing enhanced quality prey can enhance breeding and newborn quality in various species (Sargent et al., 1999; Mazorra et al., 2003; Tlusty et al., 2005; Lim et al., 2008; Ahn et al., 2011).

Production of high quality adult Artemia should ideally be based on both an effective ongrowing procedure and an efficient enrichment technique, based on mixtures of different ingredients (microalgae, commercial products). Generally, Artemia is ongrownn in large tanks, suitable for supplying high quantities of biomass (Dhont et al., 1993; Lim et al., 2008). Some circumstances require much lower quantities and consequently, small culture volumes are more suitable for ongrowing. Factors such as cyst strain, temperature and food conversion efficiency strongly influence biomass production in proportion to initial nauplii density (Sorgeloos et al., 1980).

Young Artemia is n-3 HUFA deficient (Thinh et al., 1999; Vismara et al., 2003) and an issue with its enrichment is the retroconversion of DHA into EPA, occurring particularly in younger individuals (Navarro et al., 1999). Therefore, the nutritional value of adult Artemia is superior to that of nauplii or young stages (Léger et al., 1986). Hence, the enhancement of Artemia quality would be more efficient in adults, depending on the duration and type of enrichment applied.

This study describes a simple technique for the production of adult Artemia in small volume units and assesses the effect of several ongrownn and enrichment diets (STE and LTE). A further purpose of the present study was the stable production of high quality Artemia to feed seahorse breeders maintained at our facilities (Planas et al., 2008, 2010). Results from the study were used to establish standard production and enrichment procedures in our facilitites for the rearing and breeding of seahorses in captivity, which resulted notoriously enhanced.

\section{Material and methods}

\section{Cultures of microalgae}

The strains for the cultures of Tisochrysis lutea (former Isochysis galbana T-Iso) and Phaeodactylum tricornutum were obtained from the culture collection of the Instituto de Ciencias Marinas de Andalucia (Cádiz, Spain) (CCMM Isochrysis aff. galbana T-ISO, strain 05/0401) 
(Lubián and Yúfera, 1989) and the Cambridge Culture Collection of Algae and Protozoa (CCAP, strain 1052/6), respectively. Cultures were grown on Walne medium (Walne, 1966) at $28{ }^{\circ} \mathrm{C}$, under a continuous light regime of about $60 \mu \mathrm{E} \mathrm{m}^{-1} \mathrm{~s}^{-1}$ provided by daylight fluorescent tubes. Microalgae were firstly cultured in $5 \mathrm{~L}$ flasks followed by $70 \mathrm{~L}$ plastic bags and harvested during the middle stationary phase.

\section{Production of adult Artemia}

Initially, two experiments were run in duplicate to establish an experimental procedure for Artemia ongrowing. EG Artemia cysts (Inve, Belgium) were hatched $\left(0.8 \mathrm{~g} \mathrm{~L}^{-1}\right)$ in $20 \mathrm{~L}$ seawater at $28{ }^{\circ} \mathrm{C}$. Freshly hatched nauplii were filtered, washed, and transferred to $30 \mathrm{~L}$ methacrylate cylinders ( $20 \mathrm{~cm}$ diameter; $1 \mathrm{~m}$ height). The Artemia was cultivated for 15 days in $25 \mathrm{~L}$ of highly aerated seawater at $26{ }^{\circ} \mathrm{C}$ and 38 ppt salinity. Mixtures of the microalgae Tisochrysis lutea, Prolon (Inve, Belgium; 17\% protein, 10\% ash; 6\% moisture) and freeze dried Spirulina (= Arthrospira) (Iberfrost, Spain; 60\% protein, $8 \%$ ash, $7 \%$ moisture), were fed to the Artemia. The initial culture volume $(10 \mathrm{~L})$ was daily increased $(5 \mathrm{~L})$ from days $2-4$ to reach a final and constant volume of $25 \mathrm{~L}$. From day 5 onwards, the culture media was renewed daily (about $200 \%$ water exchange), early in the morning before feeding. This cultivation procedure was established according to previous experimental trials.

- Experiment I: Initial nauplii density

Three densities of Artemia nauplii were assayed: 25,000 (x1), 50,000 (x2), and 75,000 (x3) nauplii cylinder ${ }^{-1}\left(1,2\right.$, and 3 nauplii $\mathrm{mL}^{-1}$, respectively). The general procedure and the food dose applied to treatment $x 1$ are summarized in Table 1. From day 5 of culture, treatments $x 2$ and $x 3$ received double and triple the food dose used in treatment $x 1$, respectively.

- Experiment II: Food daily ratio

According to the results achieved in Experiment I, the initial density of nauplii in this assay was established at 2 nauplii $\mathrm{mL}^{-1}$ (50,000 nauplii cylinder-1). The ongrowing procedure was the same as for Experiment I except for feeding ratios.

Three daily ratios of food ( $x 1, x 2$ and $x 3)$ were evaluated. Since day 5 of culture, the dose of food supplied to treatment $x 2$ was the same as for treatment $x 2$ in Experiment I (Table 1), whereas treatments $x 1$ and $x 3$ received half and triple the amount of food offered in treatment $x 2$, respectively.

In both experiments, $\mathrm{NO}_{2}, \mathrm{NO}_{3}$ and $\mathrm{NH}_{3}-\mathrm{NH}_{4}$ levels were checked using Sera Kits (Germany), both before and after each daily water exchange (200\%). Total length $(n=30)$ and dry weight of Artemia $(n=100)$ were analysed at different time intervals. In Experiment II, fatty acids content in $15 \mathrm{~d}$ old Artemia was also analysed.

\section{Artemia ongrowing and enrichment}

Results from Experiments I and II were used to establish final culture conditions. Four ongrowing diets $(A, B, C$ and $D)$ were assayed in $100 \mathrm{~L}$ methacrylate cylinders $(115 \times 35 \mathrm{~cm})$ for 
18 days at $26{ }^{\circ} \mathrm{C}$. The initial culture volume $(50 \mathrm{~L})$ was increased by $10 \mathrm{~L}$ per day (including microalgae volume addition) from days $2-5$ to reach a final constant volume of $95 \mathrm{~L}$. From day 5 onwards, the culture media was renewed daily (about 200\% water exchange) through different mesh size (days 5-9: $250 \mu \mathrm{m}$; days 10-18: $500 \mu \mathrm{m}$ ), early in the morning before feeding.

The ongrowing diets consisted of different combinations of live microalgae (T. lutea or $P$. tricornutum), freeze dried Spirulina, Prolon (culture and enrichment diet from Inve, Belgium) and Red Pepper (enrichment diet from Bernaqua, Belgium; $6 \%$ protein, $3 \%$ ash, $68 \%$ moisture) as shown in Table 2. Diets A and B were based on diets $x 2$ and $x 3$ in Experiment II, respectively. The composition of diet $D$ was the same as for diet $C$ but included LTE; days $10-18$ ). This consisted of an extra daily dose of Red Pepper $\left(100 \mathrm{mg} \mathrm{L}^{-1}\right)$ supplied at $6 \mathrm{pm}$ alongside the ongrowing diet.

Ten STE (A1-D10; Table 3) were carried out in 18 days-old Artemia cultivated on ongrowing diets $\mathrm{A}, \mathrm{B}, \mathrm{C}$ and $\mathrm{D}$. For this, different combinations and doses of $T$. lutea, $P$. tricornutum, Prolon, Easy DHA Selco (enrichment diet from Inve, Belgium; 0\% protein, 1\% ash, 30\% moisture), Red Pepper and 5\% v/v Artemia Condition Enhancer (Inve, Belgium) were assayed. ACE (500 mg L-1) was supplied 6 hours after the beginning of enrichment. For the enrichment, Artemia adults were collected early in the morning from the ongrowing units, then filtered, washed and transferred to $25 \mathrm{~L}$ units $\left(200\right.$ Artemia $\left.\mathrm{L}^{-1}\right)$ and enriched at $26{ }^{\circ} \mathrm{C}$ for $30 \mathrm{~h}$. Enrichment diets were administered in three daily doses (0,6 and $24 \mathrm{~h}$ ).

Duplicate samples of Artemia were taken for dry weight, lipid content and fatty acids analysis. The samples were filtered, rinsed with tap water, transferred to cryotubes, lyophilised, weighed and maintained at $-80 \stackrel{\circ}{\circ}$ within a nitrogen atmosphere.

For the purpose of comparison with adult enriched Artemia, mixtures of wild mysidaceans Leptomysis spp. (70\%) and Siriella spp. (30\%) were captured twice in Toralla Island (Vigo, Spain) in late spring. These were either submitted to starvation for 5 days or enriched for 20 hours. The enrichment consisted of a first dose of Prolon (50 mg L-1) and Red Pepper (125 mg $\left.\mathrm{L}^{-1}\right)$ for 16 hours, and a second dose of Prolon (100 mg L-1) and Red Pepper (250 mg L-1) for 4 hours. Samples were taken in duplicate for lipid content and fatty acids analysis.

Lipids were extracted from samples of microalgae, adult Artemia and mysidaceans according to Bligh and Dyer (1959) as described in Valladares and Planas (2012). Aliquots of each algae culture of known concentration were centrifuged, resuspended with $0.5 \mathrm{M}$ ammonium formate solution, freeze-dried and stored at $-80^{\circ} \mathrm{C}$ until further analyses. Total lipid content was quantified gravimetrically (Herbes and Allen, 1983). Fatty acid (FA) composition of lipids was analysed by gas-chromatography (GC) according to Christie (1982). Lipids were transmethylated (Lepage and Roy, 1986) and fatty acids analysed by GC (Perkin Elmer, Clarus 500 gas chromatograph) as described in Planas et al. (2010). Samples were analysed in duplicate. 
Data analysis

Statistical analyses were performed using the software package Statistica 8.0 (StatSoft). The results are provided as mean $\pm S D$. One-way analysis of variance (ANOVA) and post-hoc SNK test were used to check differences among treatments. Repeated measures ANOVA (RMANOVA) was used to check differences of LTE effect with time. A significance level of 0.05 was used in statistical tests. A principal component analysis was applied to FA data, which were mean centred and normalized to unit column standard deviation (SD) before calculation (Støttrup et al., 2013).

\section{Results}

\section{Artemia cultivation procedure}

The final ongrowing efficiency in Experiment I was not significantly affected by the initial density of Artemia nauplii (ANOVA, $p>0.005$ ) except for total biomass yield (ANOVA, $p=0.007$ ) (Table 4), which increased with increasing initial nauplii densities. Although not statistically significant, most parameters analysed were higher in treatment $\mathrm{x} 2$. For that reason, treatment $\mathrm{x} 2$ was selected to run Experiment II, in which the highest overall success was achieved in treatment $\mathrm{x} 3$, especially for Artemia dry weight, total biomass and ongrowing efficiency (ANOVA, $p<0.05$ ) (Table 4). Treatment $x 1$ yielded the worst results overall in both experiments.

Most mortality occurred on days 6-10 in Experiment I and 3-10 in Experiment II. In treatment $x 3$ of Experiment II, a huge increase in the levels of $\mathrm{NO}_{2}, \mathrm{NO}_{3}$ and $\mathrm{NH}_{4}-\mathrm{NH}_{3}(16.5,40$ and 0.27 $\mathrm{mg} \mathrm{L}^{-1}$, respectively) occurred during the last days of ongrowing, resulting in a further noticeable mortality. For these reasons, treatment $x 2$ was selected for the studies on the effect of ongrowing diets and enrichments.

Total lipid content and FA profiles in adult Artemia from all treatments in both experiments did not differ significantly (ANOVA, $p>0.05$ ). Total lipids ranged from 18.15 to $21.03 \%$ dry weight. The highest FA content corresponded to $16: 0,181 n-9,18: 2 n-6$ and $20: 5 n-3$, in decreasing order. DHA (22:6n3) and n-3 HUFA content ranged between 4.95-10.97 and 19.8$30.1 \mathrm{mg} \mathrm{g}^{-1}$, respectively.

\section{Fatty acids in diets and adult Artemia}

The FA composition of microalgae and commercial products used in the ongrowing and enrichment of Artemia is provided in Table 5. Dried Spirulina had the lowest lipid content and the most unbalanced FA profile, characterized by high levels in 16:0, 18:3n-6 and 18:2n-6, and by the absence of highly unsaturated fatty acids. Microalgae $P$. tricornutum and $T$. lutea showed high EPA and DHA levels, respectively. The former was also rich in 14:0, 18:1n-9 and 18:4n-3, and the latter was rich in saturates 16:0 and 16:1n7. 
The enrichers Prolon, Red Pepper and DHA Selco showed the highest n-3 HUFA content. Prolon was rich in DHA, 16:0, 18:1n-9 and to a lesser extent in EPA. Red Pepper was particularly rich in 16:0 and DHA. Finally, DHA Selco showed the most equilibrated FA profile with high content in 18:1n9, DHA and 16:0.

Adult Artemia ongrownn on tested diets (A-D) showed clear differences in the FA content, especially in n-3 HUFA (Table 6). Artemia fed on diets A and B did not differ significantly in lipid content and FA content. In both treatments, adult Artemia was rich in 16:0, 18:1n-9, 18:2n-6 and 20:5n3. Artemia from diet $C$ showed significantly increased content of 16:1n-7, 18:0 and 20:5n3 compared to treatments $A$ and $B$ but showed lower levels of 18:2n-6, 18:3n-3, 18:4n-3, 20:4n6 and 22:6n-3. Finally, the highest content of total lipids, total FA and n-3 HUFA were achieved in Artemia from diet D, due to a huge increase in 20:4n-3, EPA and especially in 22:5n-3 and DHA. Other FA content in Artemia fed on diets $C$ and $D$ was not statistically different. For these reasons, diet $\mathrm{D}$ was selected for the study on the evolution of FA content in Artemia submitted to LTE.

Regarding STE, treatments A1 and B2 (based on T. lutea and Prolon) contained the lowest total lipid and n-3 HUFA content (Table 7). A 2-fold increase of Prolon dose in both ongrowing diets $A$ and $B$ and corresponding enrichments did not significantly increase the absolute content of fatty acids.

Enrichments C3 to C7 were conducted on Artemia previously cultured on diet C (Spirulina, $P$. tricornutum and Prolon) using different enrichment combinations of $T$. lutea, Prolon, Red Pepper and Easy DHA Selco. The FA content in enrichments A1, B2 and C3 were very similar, with small but significant increases mainly in 16:0, 16:1n-7, 18:2n-6, 18:3n3 and EPA in the latter. In $\mathrm{C} 4$ - C7 Artemia, the FA contents were almost identical, with significantly higher n-3 HUFA (DHA, 22:5n-3 and EPA), 16:0 and 18:0 levels than in enrichments A1, B2 and C3. The most interesting difference among enrichments $\mathrm{C} 4-\mathrm{C} 7$ was a slight increase in DHA in $\mathrm{C} 4$ Artemia (Prolon + Easy DHA Selco). Increasing levels of Red Pepper in enrichments C5 - C7 (Prolon + Red Pepper) did not result in substantially different fatty acid content.

Finally, D8 - D10 Artemia provided the highest levels in total lipids, saturates (16:0, 18:0), n6 fatty acids (18:2n-6 and 20:4n-6), n-3 HUFA (EPA, 22:5n-3 and DHA), and DHA/EPA ratio. Increases in essential fatty acids (EFA) such as ARA, EPA and DHA were highly significant when compared to all other enrichments. Although differences among D8, D9 and D10 were scarce, the highest levels in EFA were achieved when Red Pepper was included in the enrichment (D10 and particularly D9).

Artemia ongrownn for 18 days on diet $\mathrm{D}$ which included LTE between days $10-18$, was analysed for changes in FA content over time (Figure 1). Total lipids increased from 20.7 at day 9 to $24.8,26.9$ and $26.8 \mathrm{mg} \mathrm{g}^{-1}$ at days 12,15 and 18 , respectively. Fatty acids $16: 1 \mathrm{n}-7,18: 0$, 18:1n-7 and EPA remained constant during the whole LTE period but the content of all other fatty acids increased progressively until day 15 (6 days of LTE) and then decreased slightly until 
day 18 (9 days of LTE). For most FA, significant statistical differences (RM-ANOVA) were found between days 9 and 12 but FA content at days 12, 15 and 18 were similar. However, total FA content was always highest at day 15. Subsequent STE using different combinations of Prolon and Red Pepper did not significantly increase FA content reached at day 15 (Fig. 1).

The score plots from a principal component analysis (PCA) on the FA content in adult Artemia revealed huge differences among diets and enrichments (Fig. 2). In the score plots (Fig. 2a, 2c), samples from diets A, B and C and their corresponding STE samples (right in the diagram), were clearly separated from the samples of Artemia from diet D submitted to LTE (left in the diagram). FA located to the left in the loadings plot (Fig. 2b, 2d) were those found in higher concentrations in both STE and LTE D-type Artemia, while those located to the right in the diagram corresponded to FA found in higher concentrations in ongrownn and STE Artemia from $A, B$ and to a lesser extent, $C$ treatments. The scores plot from the PCA on A- and B-type enriched Artemia (A1 and B2) were very similar, but the scores from the PCA on A- and Bongrownn Artemia (Day 18 from diets A and B) resembled those from the PCA on C-type Artemia, both enriched (C4 - C7) and non-enriched (Diet C, day 18). The interpretation of the plots was supported by raw data (Tables 6 and 7), confirming a strong positive effect of LTE on n-3 HUFA content, particularly in EPA, DHA and ARA, together with increasing DHA/EPA and DHA/ARA ratios.

Fatty acids in wild mysidaceans

Total lipids in the mixture of wild mysidaceans $(11.95 \%)$ were relatively stable both after the enrichment (13.49 - 14.15\% dry weight) and during the 5-day starvation period (10.96 - 14.35\% dry weight). Initially, EPA (14.47 $\mathrm{mg} \mathrm{g}^{-1}$ ) and DHA (13.13 $\mathrm{mg} \mathrm{g}^{-1}$ ) content was high compared to adult enriched Artemia previously ongrownn on diets A, B and C, but much lower than in D-type Artemia. Wild mysidaceans were also rich in 16:0 (13.65 $\left.\mathrm{mg} \mathrm{g}^{-1}\right)$ but poor in $18: 1 \mathrm{n}-9$ (6.20 mg g1) and 18:2n-6 (1.44 $\left.\mathrm{mg} \mathrm{g}^{-1}\right)$. DHA/EPA and DHA/ARA ratios were 0.91 and 5.54 , respectively. As for total lipids, the FA profile and DHA/EPA and DHA/ARA ratios did not differ substantially after undergoing enrichment or starvation.

\section{Discussion}

In the present study, experiments were carried out to set up a standardized procedure for the small-volume production of high nutritional quality adult Artemia and to assess how diet and enrichment influenced the fatty acids profile in adult Artemia.

In the preliminary experiments for adult Artemia production, it was used a mixture of $T$. lutea, Prolon (Inve) and freeze dried Spirulina, considering different initial nauplii densities and food doses. T. lutea was selected as a basic ingredient of the diet, whereas Spirulina and Prolon were included in the diet due to their high protein content (Ciferri, 1983) and n-3 HUFA, respectively. In addition, Spirulina is very rich in the antioxidant astaxanthin (Tlusty et al., 2005). 
The best conditions for the production of adult Artemia at $26^{\circ} \mathrm{C}$ in $25 \mathrm{~L}$ seawater were achieved with initial densities of $2-3$ nauplii $\mathrm{mL}^{-1}$ (Treatments $\mathrm{x} 2$ and $\mathrm{x} 3$ in Experiment 1 , respectively) and a daily food dose equivalent to treatment $x 2$ in Experiment I. Increasing initial nauplii densities and especially food ratios (Treatment $x 3$ in Experiment II) would be feasible for a period of time but accompanied by rising levels of metabolic waste products $\left(\mathrm{NO}_{2}, \mathrm{NO}_{3}\right.$ and $\mathrm{NH}_{4}-\mathrm{NH}_{3}$ ) and further crash of the culture. For these reasons, treatment $\mathrm{x} 2$ in both experiments was selected as the best option for culture. The overall performance of that culture conditions was as follows: $5.6-5.9 \mathrm{~mm}$ in length, $365-456 \mu \mathrm{g}$ dry weight Artemia $^{-1}$, with $44-46 \%$ final survival. The final yield was very similar to that described by Dhont and Lavens (1996) for closed systems and low initial nauplii density. However, it was higher than those previously reported for smaller volumes and higher initial nauplii densities (Espinosa-Fuentes et al., 1997; Maldonado-Montiel and Rodríguez-Canché, 2005).

The nutritional quality of Artemia biomass produced in semi-intensive or super-intensive systems is analogous to natural produced biomass except for the lipid content and fatty acids profile (Léger et al., 1986; Dhont and Lavens, 1996). The final FA profile in adult Artemia is partially dependent on the composition of the diet (Léger et al., 1986; Vismara et al., 2003). In this study, increased feed ratios (Diet A vs diet B) did not result in differences on FA content. Artemia fed on diets A and B, based on T. lutea, Prolon and Spirulina, reflected the low content in $16: 1 \mathrm{n} 7$ of $T$. lutea, and the high content of $18: 1 \mathrm{n} 9$ and 18:2n-6 in Prolon and 18:3n6 (GLA; $Y$ linolenic acid) in Spirulina. GLA is a major fatty acid in many Spirulina strains, comprising more than $25 \%$ of total FA (Cohen et al., 1983). In addition, the content of EPA and DHA was low in Artemia fed on diets $A$ and $B$, resulting in $n-3 / n-6$ values lower than in Artemia fed on diets $C$ and D.

Substituting the microalgae $T$. lutea (Diets $\mathrm{A}, \mathrm{B}$ and $\mathrm{C}$ ) for $P$. tricornutum (Diet $\mathrm{D}$ ) improved the levels of $16: 1 n-7$ and EPA but reduced those of DHA. These changes were due to $P$. tricornutum being rich in 16:1n7 and deficient in DHA. Nevertheless, long-time incorporation of a compound highly rich in DHA (Diet D) drastically enhanced the DHA content in Artemia (from $4.37 \pm 2.00 \mathrm{mg} \mathrm{g}^{-1}$ on diet $C$ to $18.84 \pm 0.32 \mathrm{mg} \mathrm{g}^{-1}$ on diet $\mathrm{D}$ ). An important advantage of diet $\mathrm{D}$ compared to other diets and enriching mixtures tested was the enhancement of ARA (from 1.71 \pm 0.31 up to $5.16 \pm 0.19 \mathrm{mg} \mathrm{g}^{-1}$ in Artemia fed on diets $C$ and D, respectively), an essential FA that plays an important role in gonad maturation and newborn quality of some fish species (Sargent et al., 1995, 2002; Mazorra et al., 2003; Furuita et al., 2007). The EPA/ARA ratio also seems to be important during ovarian development (Mazorra et al., 2003)

The importance of DHA for marine fishes is reflected in its very high content in eggs (Anderson et al., 1990). Although some fish and crustaceans are capable of synthesizing DHA and EPA from 18:3n-3 (Kanazawa et al., 1979), this is not common in marine environments. In contrast to freshwater species, physiologically essential n-3 HUFAs (EPA and DHA) in marine fish or crustaceans need to be obtained from dietary sources as they cannot be synthesized de novo from 18:3n-3 (Sargent et al., 1995; Tocher, 2003). Accordingly, n-3 HUFA requirements in 
marine fish (Sargent et al., 1989) would only be fulfilled by administering diets with adequate $n$ 3 HUFA levels.

One of the main goals of rrecent research in optimizing live food has been focused on the enhancement of n-3 HUFA content, especially in Artemia nauplii and metanauplii, common prey in the feeding schedule of larval rearing of many marine species (Léger at al., 1986; Lavens and Sorgeloos, 2000). Pre-adult and adult Artemia are suitable for juveniles and adults of some marine species such as lobsters, shrimps or prawns, whose rearing is mainly based on live prey (Léger et al., 1986; Bengtson et al., 1991). Although the use of adult enriched Artemia would ensure the administration of controlled and relatively stable FA content, its use in marine rearing systems is uncommon due partially to economic reasons.

The use of the P. tricornutum (EPA source), Spirulina (Protein source) and Red Pepper (main DHA source) yielded Artemia rich in protein with an equilibrated proportion of EPA and DHA. The quality ( $n-3$ HUFA content) of LTE Artemia was based on the equilibrium between the microalgae Those ingredients provided Artemia quality similar Red Pepper was used in LTE experiments due to its high DHA/EPA ratio, though other similar commercially available products rich in n-3 HUFA would likely provide good results. LTE were carried out on Artemia juveniles based on daily increasing doses of Dry Selco (Inve, Belgium). At 7 days old, the Artemia contained n-3 HUFA levels (64.3 $\mathrm{mg} \mathrm{g}^{-1}$ dry weight) up to five times higher than those from STE, and EPA and DHA contents of 44.2 and $16.5 \mathrm{mg} \mathrm{g}^{-1}$ dry weight, respectively (Léger et al., 1986; Dhont et al., 1993). These contents are higher than those achieved in this study for n-3 HUFA (50.05-58.03 $\mathrm{mg} \mathrm{g}^{-1}$ dry weight) and EPA (27.59-29.77 $\mathrm{mg} \mathrm{g}^{-1}$ dry weight) on STE and LTE D-type Artemia, but are lower than those for DHA (17.04 - $20.59 \mathrm{mg} \mathrm{g}^{-1}$ dry weight). Such differences among both studies are very likely due to dissimilarities between FA profiles of enrichers, strain origin, and enrichment conditions (salinity, dissolved oxygen or temperature) that might also affect Artemia physiology and FA metabolism (Léger et al., 1987; Navarro et al., 1999).

In LTE Artemia, the inclusion of Red Pepper considerably enhanced the content of ARA, EPA and DHA, and DHA/EPA and DHA/ARA ratios. DHA/EPA ratio is considered a good indicator of prey quality, and according to Tocher and Sargent (1984), the optimal ratio is about 2:1. The highest DHA/EPA values were obtained with diet $D$ submitted to enrichments D9 and D10 (0.69-0.71). However, Sargent et al. (1999) suggested an optimal level of $6.5-12.5 \%$ DHA. The use of LTE with diet D would ensure such levels and consequently this is the recommended treatment. According to the results of this study, the duration of LTE should be at least 3 days to ensure the best outcome.

Most adult fish and crustaceans are ongrownn on pellets or artificial diets but others like seahorses only accept live food. For the latter, adult Artemia can contribute significantly to partially or totally cover the daily food ratio. Mysidaceans are one of the most-used frozen organisms to feed several cultivated species. These organisms have an excellent nutritional value, partially due to their FA profile. Our analyses on Leptomysis and Siriella species showed 
that they can remain alive for a few days without food, and still provide high levels of $n-3$ HUFA and excellent DHA/EPA ratios. Interestingly, LTE Artemia showed similar or even better FA profiles (higher DHA content) and ratios compared to mysidaceans, confirming their high nutritional value.

Compared to other prey, adult Artemia produced on optimized culture and enrichment procedures, whether used alone or as a supplement, have two main advantages. They have a relatively stable, known, biochemical composition, and are continuously available. Those facts are particularly important for our purposes since the final obtective of this study was the stable production of high quality Artemia for the feeding of seahorse breeders maintained at our facilities (Planas et al., 2008, 2010). Adult seahorses are typically reared on live or frozen zooplankton (Olivotto et al., 2011). In our laboratory (IIM, CSIC), Artemia is the main prey for the feeding of seahorse breeders, being occasionally supplemented with wild caught mysidaceans. Breeders and ongrowing seahorses (Hippocampus guttulatus) were originally fed on STE Artemia (treatments A1 and B2). With that Artemia as unique food, seahorse growth was efficiently sustained but newborn quality was lower than expected. This low quality was reflected in the high rate of mouth malformations in newborn seahorses (Planas et al., 2009) and the deficient energetic status in early developing juveniles, resulting in very low initial survivals (Olivotto et al., 2011). Substituting STE with LTE Artemia drastically increased more than 3-folds the levels of total n-3 HUFA, EPA and DHA in eggs and newborn (unpub. data), and enhanced newborn quality whereas malformations were avoided, improving largely survival (e.g. up to $85 \%$ survival at day 30 in $\mathrm{H}$. guttulatus) and growth rate in juveniles (Planas et al., 2012). Currently, LTE Artemia (enrichments D9 or D10) is routinely used in our facilities as the main enrichment procedure in Artemia for the ongrowing and breeding of three seahorse species $(H$. guttulatus, $H$. abdominalis and $H$. reidi). Furthermore, the application of the ongrownn technique to a $25 \mathrm{~L}$ cultivation unit ensures the production of adult Artemia biomass required to feed 30-60 seahorse breeders for one week (Quintas et al., 2007). We have not tested LTE Artemia in species other than seahorses. However, the scope of the present study and their applicability are not restricted to seahorses but also to other species demanding prey rich in n-3 HUFA. Also, the different enrichment procedures assayed would be also useful for experimental purposes requiring different and reliable fatty acids profiles in Artemia.

In summary, this study describes a simple and reliable technique for the production of adult Artemia in small volumes. It also shows the high quality of LTE Artemia (minimum 3 days; 6-9 days recommended), regardless of further STE. The end quality of the Artemia produced containing 5.16-5.94 $\mathrm{mg} \mathrm{ARA} \mathrm{g}^{-1}$, 28.46-29.77 $\mathrm{mg} \mathrm{EPA} \mathrm{g}^{-1}$ and 18.84-20.59 $\mathrm{mg} \mathrm{DHA} \mathrm{g}^{-1}$ ). was similar to, or even higher than, that of wild mysidaceans.

\section{References}

Anderson AJ, Arthington AH, Anderson S (1990) Lipid classes and fatty acid composition of the eggs of some Australian fish. Comp. Biochem. Physiol. 96B: 267-270. 
Anh, NTN, Ut VN, Wille M, Hoa NV, Sorgeloos P (2011) Effect of different forms of Artemia biomass as a food source on survival, molting and growth rate of mud crab (Scylla paramamosain). Aquac. Nutr. 17: e549-e558.

Bengtson DA, Léger P, Sorgeloos P (1991) Use of Artemia as a food source for aquaculture. In Browne RA, Sorgeloos P, Trotman CNA (eds). Artemia Biology. CRC Press, Boca Raton, FL, USA, pp. 255285.

Bligh EG, Dyer WJ (1959) A rapid method of total lipid extraction and purification. Can. J. Biochem. Physiol. 37: 911-917.

Bruce M, Oyen F, Bell G, Asturiano JF, Farndale B, Carrillo M, Zanui S, Ramos J, Bromage N (1999) Development of broodstock diets for the European sea bass with special emphasis on the importance of $n-3$ and $n-6$ highly unsaturated fatty acids to reproductive performance. Aquaculture 177: 85-97.

Christie WW (1982) Lipid analysis. Pergamon Press, Oxford, UK, pp. 52-53.

Ciferri O (1983) Spirulina, the edible microorganism. Microbiol. Rev. 47: 551-578.

Cohen Z, Vonshak A, Richmond A (1987) Fatty acid composition of Spirulina strains grown undervarious environmental conditions. Phytochemistry 26: 2255-2258.

Dhont J, Lavens P (1996) Tank production and use of ongrown Artemia. In Lavens P, Sorgeloos (eds). Manual on the production and use of live food for aquaculture. FAO Fisheries Technical Paper 361, FAO, Rome, pp. 164-194.

Dhont J, Lavens P, Sorgeloos P (1993) Preparation and use of Artemia as food for shrimp and prawn larvae. In McKey JP (ed), CRC Handbook of Mariculture. Vol. 1. Crustacean Aquaculture. CRC Press, Inc., Boca Raton, Florida, USA, pp. 61-93.

Espinosa-Fuentes A, Ortega-Salas A, Laguarda-Figueras A (1997) Two experimental assays to produce biomass of Artemia franciscana (Anostraca). Rev. Biol. Trop. 44: 565-572.

Furuita H, Hori K, Suzuki, Sugita T, Yamamoto T (2007) Effect of n-3 and n-6 fatty acids in broodstock diet on reproduction reproduction and fatty acid composition of broodstock and eggs in the Japanese eel Anguilla japonica. Aquaculture 267: 55-61.

Herbes S, Allen C (1983) Lipid quantification of freshwater invertebrates: method modification for microquantitation. Can. J. Fish. Aquat. Sci. 40: 1315-1317.

Kanazawa A, Teshima S, Ono K (1979) Relationship between essential fatty acid requirements of aquatic animals and the capacity for bioconversion of linolenic acid to highly unsaturated fatty acids, Comp. Biochem. Physiol. B 63: 295-298.

Lavens P, Sorgeloos P (2000) The history, present status and prospects of the availability of Artemia cysts for aquaculture. Aquaculture 181: 397-403.

Léger Ph, Naessens-Foucquaert E, Sorgeloos P (1987) International study on Artemia XXXV. Techniques to manipulate the fatty acid profile in Artemia nauplii and the effect on its nutritional effectiveness for the marine crustacean Mysidopsis bahia (M). In Sorgeloos P, Bengtson DA, Decleir W, Jaspers E (eds). Artemia research and its applications, Vol. 3. Ecology, Culturing, Use in Aquaculture. Universa Press, Wetteren, Belgium, pp. 411-424.

Léger P, Bengtson DA, Simpson KL, Sorgeloos P (1986) The use and nutritional value of Artemia as a food source. Oceanogr. Mar. Biol. Ann. Rev. 24: 521-623.

Lepage G, Roy C (1986) Direct transesterification of cell classes of lipids in a one step reaction. J. Lipid Res. 27: 114-120. 
Lim LC, Soh A, Dhert P, Sorgeloos P (2008) Production and application of on-grown Artemia in freshwater ornamental fish farm. Aquac. Eco. Manag. 5: 211-228.

Lubián LM, Yúfera. M (1989) Colección de cepas de microal-gas marinas del Instituto de Ciencias de Andalucia (CSIC). In Yúfera M (ed). Acuiculturura Internameal. Consejo Superior de Investigariones cientificas, Cádiz, pp. 66-78.

Maldonado-Montiel TD, Rodríguez-Canché LG (2005) Biomass production and nutritional value of Artemia sp. (Anostraca: Artemiidae) in Campeche, México. Rev. Biol. Trop. 53: 447-454.

Mazorra C, Bruce M, Bell JG, Davie A, Alorend E, Jordan N, Rees J, Papanikos N, Porter M, Bromage N (2003) Dietary lipid enhancement of broodstock reproductive performance and egg and larval quality in Atlantic halibut (Hippoglossus hippoglossus). Aquaculture 227: 21-33.

Navarro JC, Henderson RJ, McEvoy LA, Bell MV, Amat F (1999) Lipid conversions during enrichment of Artemia. Aquaculture 174: 155-166.

Olivotto I, Planas M, Simões N, Holt GJ, Avella MA Calado R (2011) Advances in beeding and rearing marine ornamentals. J. World Aquacult. Soc. 42: 135-166.

Planas M, Chamorro A, Quintas P, Vilar A (2008) Establishment and maintenance of threatened longsnouted seahorse Hippocampus guttulatus, broodstock in captivity, Aquaculture 283: 19-28.

Planas M, Quintas P, Chamorro A (2009) Snout abnormalities in young seahorses (Hippocampus guttulatus) (Project Hippocampus). Book of Abstracts, World Aquaculture 2009, World Aquaculture Society, p. 668.

Planas M, Quintas P, Chamorro A, Silva C (2010) Female maturation, egg characteristics and fatty acids profile in the European long-snouted seahorse Hippocampus guttulatus. Anim. Rep. Sci. 122: 66-73.

Planas M, Blanco A, Chamorro A, Valladares S, Pintado J (2012) Temperature-induced changes of growth and survival in the early development of the seahorse Hippocampus guttulatus. J. Exp. Mar.Biol. Ecol. 438: 154-162.

Quintas, P., Chamorro, A., Piñero, S., Medina, I., Planas, M., 2007. Producción de Artemia para la alimentación del caballito de mar Hippocampus guttulatus Cuvier 1829 en cautividad. XI Congreso Nacional de Acuicultura. Vigo, Spain, 24-28 September 2007, 555-558.

Sargent JR, Henderson RJ, Tocher DR (1989) The lipids. In Halver J (ed), Fish Nutrition, 2nd edn. Academic Press, New York, USA, pp. 153-218.

Sargent JR, Bell MV, Bell JG, Henderson RJ, Tocher DR (1995) Origins and functions of n-3 polyunsaturated fatty acids in marine organisms. In Cevc G., Paltauf $F$ (eds). Proceedings of the 6th International Colloquium: Phospholipids: characterization, metabolism, and novel biological applications. 1995 pp. 248-259

Sargent J. McEvoy L, Estévez A, Bell G, Bell M, Henderson J, Tocher D (1999) Lipid nutrition of marine fish during early development: current status and future directions. Aquaculture 179: 217-229.

Sargent JR, Bell JG, Tocher DR (2002) The lipids. In Fish Nutrition, 3 edn (Halver JE. Hardy RW (eds). Academic Press, San Diego, California, USA, pp. 181-257.

Sorgeloos P (1980) The use of brine shrimp Artemia in aquaculture, p. 25-45. In Persoone G, Sorgeloos P, Roels O, Jaspers E (eds). The brine shrimp Artemia. Vol. 3. Ecology, culturing, use in aquaculture. Universa Press, Wetteren, Belgium. pp.25-46.

Støttrup JG, Jacobsen C, Tomkiewicz T, Jarlbaek H (2013) Modification of essential fatty acid composition in broostock of cultured European eel Anguilla anguilla L. Aquacult. Nutr. 19: 172-185. 
Thinh LV, Renaud SM, Parry DL (1999) Evaluation of recently isolated Australian tropical microalgae for the enrichment of the dietary value of brine shrimp, Artemia nauplii. Aquaculture 170: 161-173.

Tlusty MF, Goldstein J, Fiore D (2005) Hatchery performance of early benthic juvenile American lobsters (Homarus americanus) fed enriched frozen adult Artemia diets, Aquacult. Nutr. 11: 191-198.

Tocher DR (2003) Metabolism and functions of lipids and fatty acids in Teleost fish. Rev. Fish. Sci. 11: 107-184.

Tocher DR, Sargent JR (1984) Analysis of lipids and fatty acids in ripe roes of some northwest European marine fish. Lipids 19: 492-499.

Valladares S, Planas M (2012) Non-lethal dorsal fin sampling for stable isotope analysis in seahorses. Aquat. Ecol. 46: 363-370.

Vismara R, Vestri S, Barsanti L, Gualtieri P (2003) Diet-induced variations in fatty acid content and composition of two on-grown stages of Artemia salina. J. Appl. Phycol. 15: 477-483.

Walne PR (1966) Experiments in the large scale culture of the larvae of Ostrea edulis. Fishery Invest., Lond. Ser. II. 25: 53 pp. 
Table 1.

Culture conditions for the ongrownn of Artemia in treatment $x 1$ of Experiment I. Treatments $x 2$ and $x 3$ received 2 and 3 -folds the food dose supplied in treatment $x 1$, including $T$. lutea addition from day 8 onwards). T. lutea culture was aprox $8 \times 10^{6}$ cells $\mathrm{mL}^{-1}$.

\begin{tabular}{|c|c|c|c|c|c|c|}
\hline Days & $\begin{array}{l}\text { T. lutea } \\
\qquad\end{array}$ & $\begin{array}{l}\text { Prolon } \\
\mathrm{mg} \mathrm{L}^{-1}\end{array}$ & $\begin{array}{l}\text { Spirulina sp. } \\
\qquad \mathrm{mg} \mathrm{L}^{-1}\end{array}$ & $\begin{array}{l}\text { Water Exchange / } \\
\text { Mesh size }\end{array}$ & $\begin{array}{c}\text { Volume } \\
\text { L }\end{array}$ & Aeration \\
\hline 1 & $9 \mathrm{am}: 3$ & \multirow[t]{2}{*}{ - } & \multirow[t]{2}{*}{ - } & \multirow{2}{*}{-} & 10 & \multirow{2}{*}{ Weak } \\
\hline $2-4$ & 9 am: 5 & & & & $\begin{array}{l}15-20- \\
25\end{array}$ & \\
\hline $5-7$ & \multirow{2}{*}{9 am: 2.5} & $\begin{array}{l}9 \text { am: } 5 \\
6 \text { pm: } 10\end{array}$ & $\begin{array}{l}9 \mathrm{am}: 12.5 \\
6 \mathrm{pm}: 25\end{array}$ & $\begin{array}{l}\text { Flow rate: } 6 \mathrm{~L} \mathrm{~min}^{-1} \\
\text { for } 20 \mathrm{~min} \\
\text { Mesh: } 250 \mu \mathrm{m}\end{array}$ & \multirow{2}{*}{25} & Moderate \\
\hline $8-15$ & & $\begin{array}{l}9 \text { am: } 10 \\
6 \text { pm: } 20\end{array}$ & $\begin{array}{l}9 \text { am: } 25 \\
6 \text { pm: } 50\end{array}$ & $\begin{array}{l}\text { Flow rate: } 10 \mathrm{~L} \mathrm{~min}^{-1} \\
\text { for } 20 \mathrm{~min} \\
\text { Mesh: } 500 \mu \mathrm{m}\end{array}$ & & High \\
\hline
\end{tabular}


Table 2.

Composition and daily doses of diets A, B, C and D for the ongrowing of Artemia in $95 \mathrm{~L}$ seawater. "From day 10.

\begin{tabular}{|c|c|c|c|c|}
\hline \multirow[b]{3}{*}{$\begin{array}{l}\text { Days } \\
\text { (Vol) }\end{array}$} & \multirow[b]{3}{*}{ Time } & \multirow{2}{*}{\multicolumn{3}{|c|}{ Ongrowing diets }} \\
\hline & & & & \\
\hline & & A & B & $\mathrm{D}$ \\
\hline $\begin{array}{c}1-4 \\
(60-90 \mathrm{~L}) \\
\end{array}$ & $9 \mathrm{am}$ & \multicolumn{2}{|c|}{ Tisochrysis lutea $(5 \mathrm{~L})$} & Phaeodactylum tricornutum (4-6 L) \\
\hline \multirow{6}{*}{$\begin{array}{l}5-7 \\
(95 \mathrm{~L})\end{array}$} & & \multicolumn{2}{|c|}{ Tisochrysis lutea (3-4 L) } & \\
\hline & $9 \mathrm{am}$ & \multirow{2}{*}{\multicolumn{2}{|c|}{$\begin{array}{l}\text { Spirulina sp. (25 mg L-1) } \\
\left.\text { Prolon (10 } \mathrm{mg} \mathrm{L}^{-1}\right)\end{array}$}} & Phaeodactylum tricornutum $(8 \mathrm{~L})$ \\
\hline & & & & \\
\hline & & \multirow{3}{*}{\multicolumn{2}{|c|}{$\begin{array}{l}\text { Spirulina sp. }\left(50 \mathrm{mg} \mathrm{L}^{-1}\right) \\
\text { Prolon }\left(20 \mathrm{mg} \mathrm{L}^{-1}\right)\end{array}$}} & Phaeodactylum tricornutum (4 L) \\
\hline & $6 \mathrm{pm}$ & & & Spirulina sp. $\left(15 \mathrm{mg} \mathrm{L}^{-1}\right)$ \\
\hline & & & & Prolon $\left(6 \mathrm{mg} \mathrm{L}^{-1}\right)$ \\
\hline \multicolumn{5}{|c|}{ Tisochrysis lutea (3-4 L) } \\
\hline \multirow{6}{*}{$\begin{array}{l}8-18 \\
(95 L)\end{array}$} & $9 \mathrm{am}$ & Spirulina sp. (25 mg L-1) & Spirulina sp. (50 mg L-1) & Phaeodactylum tricornutum (8 L) \\
\hline & & Prolon $\left(10 \mathrm{mg} \mathrm{L}^{-1}\right)$ & Prolon $\left(20 \mathrm{mg} \mathrm{L}^{-1}\right)$ & \\
\hline & \multirow{4}{*}{$6 \mathrm{pm}$} & & & Phaeodactylum tricornutum (4 L) \\
\hline & & & & Spirulina sp. $\left(30 \mathrm{mg} \mathrm{L}^{-1}\right)$ \\
\hline & & Spirulina sp. $\left(50 \mathrm{mg} \mathrm{L}^{-1}\right)$ & Spirulina sp. $\left(100 \mathrm{mg} \mathrm{L}^{-1}\right)$ & Prolon $\left(12 \mathrm{mg} \mathrm{L}^{-1}\right)$ \\
\hline & & Prolon $\left(20 \mathrm{mg} \mathrm{L}^{-1}\right)$ & Prolon $\left(40 \mathrm{mg} \mathrm{L}^{-1}\right)$ & Red Pepper (100 mg L-1) \\
\hline
\end{tabular}


Table 3.

Ingredients and doses used in STE Artemia (18 days) previously ongrownn on diets A, B, C and D (STE: A1 - D10). Tiso - T. lutea; P - Prolon; DHA Selco - Easy DHA Selco; RP - Red Pepper.

\begin{tabular}{|c|c|c|c|c|c|}
\hline \multirow{2}{*}{$\begin{array}{l}\text { Diet of } \\
\text { ongrowing }\end{array}$} & \multicolumn{5}{|c|}{ Short-time enrichment (STE) } \\
\hline & Ingredients & Type & $0-6$ Hours & $6-24$ Hours & 24 - 30 Hours \\
\hline$A$ & \multirow{3}{*}{$\begin{array}{l}\text { Microalgae } \\
+ \text { Prolon }\end{array}$} & A1 & $\begin{array}{l}\text { Tiso }\left(0.2 \mathrm{~L} \mathrm{~L}^{-1}\right) \\
\mathrm{P}\left(50 \mathrm{mg} \mathrm{L}^{-1}\right)\end{array}$ & \multirow{2}{*}{ Tiso $\left(0.2 L^{-1}\right)$} & \multirow{2}{*}{ Tiso $\left(0.6 L^{-1}\right)$} \\
\hline B & & B2 & $\begin{array}{l}\text { Tiso }\left(0.2 L^{-1}\right) \\
P\left(100 \mathrm{mg} \mathrm{L}^{-1}\right)\end{array}$ & & \\
\hline \multirow{5}{*}{ C } & & C3 & Tiso $\left(0.5 L^{-1}\right)$ & $P\left(100 \mathrm{mg} \mathrm{L}^{-1}\right)$ & Tiso $\left(0.6 L^{-1}\right)$ \\
\hline & $\begin{array}{c}\text { Prolon + } \\
\text { DHA Selco }\end{array}$ & C4 & \multirow{5}{*}{$P\left(100 \mathrm{mg} \mathrm{L}^{-1}\right)$} & \multirow{5}{*}{$P\left(200 \mathrm{mg} \mathrm{L}^{-1}\right)$} & $\begin{array}{l}\text { DHA Selco } \\
\left(250 \mathrm{mg} \mathrm{L}^{-1}\right)\end{array}$ \\
\hline & \multirow{3}{*}{$\begin{array}{l}\text { Prolon + } \\
\text { Red Pepper }\end{array}$} & C5 & & & $\mathrm{RP}\left(150 \mathrm{mg} \mathrm{L}^{-1}\right)$ \\
\hline & & C6 & & & $\mathrm{RP}\left(300 \mathrm{mg} \mathrm{L}^{-1}\right)$ \\
\hline & & $\mathrm{C7}$ & & & $\mathrm{RP}\left(600 \mathrm{mg} \mathrm{L}^{-1}\right)$ \\
\hline \multirow{3}{*}{ D } & Prolon & D8 & & & \\
\hline & Red Pepper & D9 & $\mathrm{RP}\left(250 \mathrm{mg} \mathrm{L}^{-1}\right)$ & $\mathrm{RP}\left(500 \mathrm{mg} \mathrm{L}^{-1}\right)$ & \\
\hline & $\begin{array}{c}\text { Prolon + } \\
\text { Red Pepper }\end{array}$ & D10 & $\begin{array}{c}P\left(50 \mathrm{mg} \mathrm{L}^{-1}\right) \\
R P\left(125 \mathrm{mg} \mathrm{L}^{-1}\right)\end{array}$ & $\begin{array}{c}P\left(100 \mathrm{mg} \mathrm{L}^{-1}\right) \\
\mathrm{RP}\left(250 \mathrm{mg} \mathrm{L}^{-1}\right)\end{array}$ & \\
\hline
\end{tabular}


Table 4.

The effect of initial nauplii density (Experiment 1) and food dose (Experiment II) on the final performance (survival, length, dry weight, total biomass and culture efficiency) in Artemia ongrowing. Different letters $(a-c)$ between treatments indicate significant differences (Post-hoc SNK Test, $p<0.05)$.

\begin{tabular}{|c|c|c|c|c|c|c|c|c|}
\hline & \multirow{2}{*}{\multicolumn{4}{|c|}{ EXPERIMENT I - Initial density (nauplii $\mathrm{ml}^{-1}$ ) }} & \multirow{2}{*}{\multicolumn{4}{|c|}{ EXPERIMENT II - Food Dose }} \\
\hline & & & & & & & & \\
\hline & $\mathrm{x} 1$ & x2 & x3 & $\mathrm{p}(\mathrm{ANOVA})$ & $\mathrm{x} 1$ & x2 & x3 & $p($ ANOVA) \\
\hline Survival (\%) & $64 \pm 8^{\mathrm{a}}$ & $46 \pm 8^{a}$ & $47 \pm 4^{a}$ & 0.136 & $33 \pm 4^{a}$ & $44 \pm 2^{a}$ & $48 \pm 8^{a}$ & 0.117 \\
\hline Length $(\mathrm{mm})$ & $5.1 \pm 0.6^{a}$ & $5.6 \pm 0.1^{a}$ & $5.5 \pm 0.5^{a}$ & 0.591 & $4.6 \pm 0.8^{a}$ & $5.9 \pm 0.1^{\mathrm{ab}}$ & $6.9 \pm 0.3^{b}$ & 0.045 \\
\hline Dry Weight ( $\mu$ g Artemia $^{-1}$ ) & $330 \pm 87^{a}$ & $456 \pm 97^{a}$ & $399 \pm 6^{a}$ & 0.369 & $210 \pm 49^{a}$ & $365 \pm 66^{a}$ & $610 \pm 28^{b}$ & 0.009 \\
\hline Total Biomass (g DW) & $6.3 \pm 1.0^{a}$ & $12.6 \pm 0.3^{b}$ & $16.9 \pm 1.8^{c}$ & 0.007 & $4.1 \pm 0.4^{a}$ & $9.5 \pm 1.3^{b}$ & $17.5 \pm 2.3^{c}$ & 0.007 \\
\hline $\begin{array}{l}\text { Efficiency ( } \mu \text { g produced } \\
\text { per initial nauplii) }\end{array}$ & $202 \pm 67^{a}$ & $216 \pm 39^{a}$ & $199 \pm 44^{\mathrm{a}}$ & 0.945 & $64 \pm 4^{a}$ & $139 \pm 27^{a}$ & $284 \pm 3^{b}$ & 0.002 \\
\hline
\end{tabular}


Table 5.

Main fatty acids ( $\mathrm{mg} \mathrm{g}^{-1}$ ) and lipid content (Dry weight percentage) in ongrowing and enrichment diets (Two replicates). Main fatty acids are given in bold.

\begin{tabular}{ccccccc}
\hline Fatty Acids & $\begin{array}{c}\text { Tisochysis } \\
\text { lutea }\end{array}$ & $\begin{array}{c}\text { Phaeodactylum } \\
\text { tricornutum }\end{array}$ & Spirulina sp. & Prolon & Red Pepper & DHA Selco \\
\hline $14: 0$ & $\mathbf{1 3 . 6 8}$ & 16.32 & 1.08 & 15.13 & $\mathbf{3 2 . 1 5}$ & $\mathbf{3 2 . 6 7}$ \\
$16: 0$ & 7.63 & $\mathbf{3 6 . 5 4}$ & $\mathbf{2 8 . 3 0}$ & $\mathbf{6 7 . 8 4}$ & $\mathbf{1 4 0 . 4 7}$ & $\mathbf{1 4 1 . 7 9}$ \\
$16: 1 \mathrm{n}-7$ & 4.91 & $\mathbf{5 9 . 1 5}$ & 2.19 & 18.66 & 3.89 & $\mathbf{4 1 . 1 6}$ \\
$18: 0$ & 0.69 & 9.02 & 0.76 & 17.17 & 8.75 & $\mathbf{3 8 . 8 7}$ \\
$18: 1 \mathrm{n}-7$ & 1.65 & 0.87 & 0.24 & 9.74 & 1.75 & 23.53 \\
$18: 1 \mathrm{n}-9$ & $\mathbf{1 4 . 6 8}$ & 14.60 & 1.11 & $\mathbf{5 6 . 0 6}$ & $\mathbf{2 3 . 9 6}$ & $\mathbf{1 6 5 . 4 1}$ \\
$18: 2 \mathrm{n}-6$ & 2.51 & 2.26 & $\mathbf{9 . 5 8}$ & 17.30 & $\mathbf{3 1 . 9 6}$ & 80.21 \\
$18: 3 \mathrm{n}-3$ & 6.15 & 0.95 & - & 3.90 & 1.50 & 18.13 \\
$18: 3 \mathrm{n}-6$ & 0.23 & 0.75 & $\mathbf{1 2 . 7 3}$ & 0.00 & 1.15 & 0.00 \\
$18: 4 \mathrm{n}-3$ & $\mathbf{1 6 . 0 7}$ & 0.12 & - & 4.32 & 1.81 & 8.15 \\
$20: 1 \mathrm{n}-9$ & 0.12 & 0.22 & - & 7.59 & 0.67 & 16.09 \\
$20: 4 \mathrm{n}-3$ & 0.21 & 0.48 & - & 2.61 & 2.63 & 6.34 \\
$20: 4 \mathrm{n}-6$ (ARA) & 0.56 & 0.82 & - & 7.62 & 5.66 & 12.22 \\
$20: 5 n-3$ (EPA) & 0.79 & $\mathbf{3 5 . 5 5}$ & - & $\mathbf{3 1 . 1 9}$ & 8.55 & $\mathbf{5 5 . 2 0}$ \\
22:5n-3 & 0.30 & 0.14 & - & 7.45 & 2.08 & 21.64 \\
$22: 6 n-3$ (DHA) & $\mathbf{1 1 . 7 3}$ & 0.77 & - & $\mathbf{8 6 . 4 8}$ & $\mathbf{1 2 0 . 6}$ & $\mathbf{1 5 2 . 1 8}$ \\
\hline Total FA & 81.90 & 178.57 & 56.0 & 353.05 & 387.6 & 813.6 \\
Saturates & 22.00 & 61.89 & 30.13 & 100.15 & 181.4 & 213.3 \\
Monounsaturates & 21.36 & 74.84 & 3.54 & 92.05 & 30.3 & 246.2 \\
Polyunsaturates & 38.54 & 41.84 & 22.31 & 160.86 & 176.0 & 354.1 \\
n-3 HUFA & 13.02 & 36.94 & - & 127.72 & 133.8 & 235.4 \\
n-3 & 35.23 & 38.01 & - & 135.94 & 137.2 & 261.6 \\
n-6 & 3.30 & 3.82 & 22.31 & 24.92 & 38.8 & 92.4 \\
n-3 / n-6 & 10.70 & 9.95 & 0.00 & 5.45 & 3.54 & 2.83 \\
DHA / EPA & 14.85 & 0.02 & - & 2.77 & 14.12 & 2.76 \\
DHA / ARA & 20.95 & 0.94 & - & 11.35 & 21.30 & 12.45 \\
Lipids (\%) & 26.95 & 33.72 & 11.81 & 45.25 & 58.40 & 100 \\
\hline
\end{tabular}


Table 6.

Fatty acid composition ( $\mathrm{mg} \mathrm{g}^{-1}$ ) and total lipids (dry weight percentage) in adult Artemia cultivated on diets A, B, C and D. Different letters (a-c) between treatments indicate significant differences (ANOVA and post-hoc SNK Test, $p<0.05$ ). Data are given as mean $\pm s d$ (Two replicates)

\begin{tabular}{|c|c|c|c|c|c|c|c|c|c|c|c|c|}
\hline \multirow{2}{*}{ Fatty Acids } & \multicolumn{12}{|c|}{ Diet } \\
\hline & & A & & & B & & & C & & & D & \\
\hline $14: 0$ & 4.37 & \pm & $0.52^{\mathrm{a}}$ & 5.18 & \pm & $1.32^{\mathrm{a}}$ & 5.24 & \pm & $0.01^{a}$ & 7.08 & \pm & $0.22^{a}$ \\
\hline $16: 0$ & 26.58 & \pm & $2.76^{a}$ & 28.71 & \pm & $1.56^{\mathrm{a}}$ & 26.12 & \pm & $0.92^{\mathrm{a}}$ & 32.48 & \pm & $0.52^{\mathrm{a}}$ \\
\hline $16: 1 n-7$ & 8.58 & \pm & $1.13^{\mathrm{a}}$ & 9.95 & \pm & $0.94^{a}$ & 25.09 & \pm & $0.31^{\mathrm{b}}$ & 23.33 & \pm & $0.78^{b}$ \\
\hline 18:0 & 8.96 & \pm & $0.19^{a}$ & 9.24 & \pm & $0.06^{a}$ & 11.34 & \pm & $1.31^{\mathrm{b}}$ & 11.26 & \pm & $0.18^{\mathrm{b}}$ \\
\hline $18: 1 n-7$ & 7.59 & \pm & $0.46^{\mathrm{ab}}$ & 8.27 & \pm & $0.00^{b}$ & 7.87 & \pm & $0.09^{a b}$ & 7.03 & \pm & $0.13^{a}$ \\
\hline $18: 1 n-9$ & 26.32 & \pm & $2.62^{a}$ & 28.88 & \pm & $1.16^{a}$ & 21.26 & \pm & $3.77^{a}$ & 24.51 & \pm & $0.39^{a}$ \\
\hline $18: 2 n-6$ & 16.95 & \pm & $1.74^{\mathrm{b}}$ & 18.07 & \pm & $0.50^{b}$ & 11.03 & \pm & $1.28^{\mathrm{a}}$ & 16.73 & \pm & $0.30^{\mathrm{b}}$ \\
\hline $18: 3 n-3$ & 3.44 & \pm & $0.04^{b c}$ & 3.95 & \pm & $1.18^{\mathrm{c}}$ & 1.83 & \pm & $0.39^{a}$ & 2.17 & \pm & $0.02^{\mathrm{ab}}$ \\
\hline $18: 3 n-6$ & 6.46 & \pm & $2.01^{a}$ & 7.86 & \pm & $0.60^{\mathrm{a}}$ & 4.84 & \pm & $0.03^{a}$ & 3.93 & \pm & $0.15^{a}$ \\
\hline $18: 4 n-3$ & 2.70 & \pm & $0.33^{b}$ & 3.15 & \pm & $1.50^{\mathrm{b}}$ & 1.04 & \pm & $0.11^{\mathrm{a}}$ & 1.55 & \pm & $0.02^{\mathrm{ab}}$ \\
\hline $20: 1 n-9$ & 0.94 & \pm & $0.31^{a}$ & 1.16 & \pm & $0.08^{\mathrm{a}}$ & 0.92 & \pm & $0.08^{a}$ & 0.77 & \pm & $0.02^{\mathrm{a}}$ \\
\hline $20: 4 n-3$ & 0.53 & \pm & $0.06^{a}$ & 0.61 & \pm & $0.11^{\mathrm{a}}$ & 0.53 & \pm & $0.16^{\mathrm{a}}$ & 1.02 & \pm & $0.00^{b}$ \\
\hline $20: 4 n-6$ (ARA) & 2.94 & \pm & $0.08^{b}$ & 2.89 & \pm & $0.19^{b}$ & 1.71 & \pm & $0.31^{\mathrm{a}}$ & 5.16 & \pm & $0.19^{c}$ \\
\hline $20: 5 n-3$ (EPA) & 14.22 & \pm & $0.88^{\mathrm{a}}$ & 14.62 & \pm & $0.99^{a}$ & 21.18 & \pm & $1.44^{b}$ & 28.64 & \pm & $0.21^{c}$ \\
\hline $22: 5 n-3$ & 0.74 & \pm & $0.11^{\mathrm{a}}$ & 0.86 & \pm & $0.12^{\mathrm{a}}$ & 0.85 & \pm & $0.44^{\mathrm{a}}$ & 5.65 & \pm & $0.06^{b}$ \\
\hline $22: 6 n-3(\mathrm{DHA})$ & 7.88 & \pm & $0.37^{a b}$ & 8.83 & \pm & $1.89^{\mathrm{b}}$ & 4.37 & \pm & $2.00^{a}$ & 18.84 & \pm & $0.32^{c}$ \\
\hline Total FA & 139.20 & \pm & $11.0^{\mathrm{a}}$ & 152.20 & \pm & $12.20^{a}$ & 145.24 & \pm & $9.61^{a}$ & 190.10 & \pm & $2.32^{b}$ \\
\hline Saturates & 39.91 & \pm & $3.46^{a}$ & 43.13 & \pm & $2.94^{a}$ & 42.71 & \pm & $0.40^{\mathrm{a}}$ & 50.81 & \pm & $0.91^{b}$ \\
\hline Monounsaturates & 43.43 & \pm & $4.53^{\mathrm{a}}$ & 48.27 & \pm & $2.17^{a}$ & 55.15 & \pm & $3.91^{\mathrm{a}}$ & 55.64 & \pm & $1.32^{\mathrm{a}}$ \\
\hline Polyunsaturates & 55.87 & \pm & $3.05^{a}$ & 60.85 & \pm & $7.08^{a}$ & 47.38 & \pm & $6.11^{a}$ & 83.69 & \pm & $0.09^{b}$ \\
\hline n-3 HUFA & 23.38 & \pm & $0.34^{a}$ & 24.92 & \pm & $3.11^{\mathrm{a}}$ & 26.93 & \pm & $4.04^{\mathrm{a}}$ & 54.15 & \pm & $0.17^{\mathrm{b}}$ \\
\hline$n-3$ & 29.52 & \pm & $0.63^{a}$ & 32.02 & \pm & $5.79^{a}$ & 29.80 & \pm & $4.55^{\mathrm{a}}$ & 57.87 & \pm & $0.17^{a}$ \\
\hline$n-6$ & 26.36 & \pm & $3.67^{b}$ & 28.83 & \pm & $1.29^{b}$ & 17.58 & \pm & $1.56^{\mathrm{a}}$ & 25.82 & \pm & $0.26^{b}$ \\
\hline$n-3 / n-6$ & 1.12 & \pm & $0.18^{a}$ & 1.11 & \pm & $0.15^{\mathrm{a}}$ & 1.69 & \pm & $0.11^{\mathrm{b}}$ & 2.24 & \pm & $0.03^{c}$ \\
\hline DHA / EPA & 0.55 & \pm & $0.06^{b}$ & 0.60 & \pm & $0.09^{b}$ & 0.20 & \pm & $0.08^{a}$ & 0.66 & \pm & $0.02^{\mathrm{b}}$ \\
\hline DHA / ARA & 2.68 & \pm & $0.20^{a}$ & 3.06 & \pm & $0.46^{a}$ & 2.50 & \pm & $0.72^{\mathrm{a}}$ & 3.65 & \pm & $0.07^{a}$ \\
\hline Lipids (\%) & 20.61 & \pm & $0.89^{a}$ & 21.03 & \pm & $1.30^{\mathrm{a}}$ & 21.44 & \pm & $2.44^{a}$ & 26.85 & \pm & $0.06^{b}$ \\
\hline
\end{tabular}


Table 7.

Fatty acid composition ( $\mathrm{mg} \mathrm{g}^{-1}$ ) and total lipids (dry weight percentage) in adult Artemia submitted to STE (A1 to D10) (Letters A, B, C and D indicate the type of ongrowing diet). Different letters (a-g) between treatments indicate significant differences (ANOVA and post-hoc SNK Test, $p<0.05)$. Standard deviations are not shown for clarity $(n=2)$.

\begin{tabular}{|c|c|c|c|c|c|c|c|c|c|c|}
\hline \multirow[b]{2}{*}{ Fatty Acids } & \multicolumn{10}{|c|}{ Artemia enrichment } \\
\hline & $\mathrm{A} 1$ & B2 & C3 & $\mathrm{C} 4$ & C5 & $\mathrm{C} 6$ & C7 & D8 & D9 & D10 \\
\hline $14: 0$ & $3.94^{a}$ & $3.81^{a}$ & $7.47^{d}$ & $5.14^{b}$ & $5.24^{b}$ & $5.16^{b}$ & $5.04^{b}$ & $6.34^{c}$ & $7.68^{d}$ & $7.35^{d}$ \\
\hline $16: 0$ & $14.18^{a}$ & $15.16^{\mathrm{a}}$ & $20.99^{b}$ & $27.96^{c}$ & $27.42^{c}$ & $27.02^{c}$ & $26.34^{c}$ & $31.69^{d}$ & $37.09^{f}$ & $35.59^{e}$ \\
\hline $16: 1 n-7$ & $5.93^{a}$ & $6.36^{\mathrm{a}}$ & $13.45^{b}$ & $21.33^{\mathrm{cd}}$ & $22.27^{d}$ & $22.10^{\mathrm{cd}}$ & $21.58^{\mathrm{cd}}$ & $20.71^{c}$ & $23.78^{e}$ & $22.27^{d}$ \\
\hline 18:0 & $6.50^{\mathrm{a}}$ & $6.93^{a}$ & $7.20^{\mathrm{a}}$ & $12.00^{d}$ & $10.24^{\mathrm{bc}}$ & $10.38^{b c}$ & $9.91^{\mathrm{b}}$ & $10.95^{\mathrm{cd}}$ & $11.91^{\mathrm{e}}$ & $11.34^{\text {de }}$ \\
\hline $18: 1 n-7$ & $6.11^{a}$ & $6.40^{\mathrm{a}}$ & $7.61^{c}$ & $8.29^{d}$ & $7.60^{c}$ & $7.47^{c}$ & $7.28^{b c}$ & $6.94^{\mathrm{b}}$ & $7.54^{c}$ & $7.21^{b c}$ \\
\hline $18: 1 n-9$ & $22.52^{\mathrm{a}}$ & $23.49^{a}$ & $25.92^{b}$ & $27.30^{\mathrm{bc}}$ & $27.00^{\mathrm{bc}}$ & $26.38^{b c}$ & $25.81^{b}$ & $26.85^{b c}$ & $28.00^{c}$ & $27.79^{c}$ \\
\hline $18: 2 n-6$ & $9.56^{\mathrm{a}}$ & $10.55^{b}$ & $14.00^{\mathrm{b}}$ & $13.75^{b}$ & $14.21^{b}$ & $13.99^{b}$ & $13.70^{\mathrm{b}}$ & $18.15^{c}$ & $19.69^{d}$ & $19.68^{d}$ \\
\hline $18: 3 n-3$ & $4.51^{c}$ & $4.58^{c}$ & $6.04^{d}$ & $2.57^{a b}$ & $2.56^{a b}$ & $2.54^{\mathrm{ab}}$ & $2.45^{\mathrm{ab}}$ & $2.64 b$ & $2.38^{a}$ & $2.48^{a b}$ \\
\hline $18: 3 n-6$ & $3.24^{\mathrm{a}}$ & $3.37^{a}$ & $5.02^{d}$ & $4.08^{c}$ & $3.81^{b c}$ & $3.86^{b c}$ & $3.73^{b}$ & $3.24^{a}$ & $3.86^{b c}$ & $3.56^{\mathrm{ab}}$ \\
\hline $18: 4 n-3$ & $8.20^{\mathrm{de}}$ & $7.63^{d}$ & $8.68^{e}$ & $1.47^{b}$ & $1.25^{a}$ & $1.24^{a}$ & $1.21^{\mathrm{a}}$ & $1.50^{\mathrm{bc}}$ & $1.64^{c}$ & $1.53^{\mathrm{bc}}$ \\
\hline $20: 1 n-9$ & $0.71^{a b}$ & $0.78^{b c}$ & $0.62^{a}$ & $1.65^{\mathrm{e}}$ & $1.05^{d}$ & $1.08^{d}$ & $1.05^{d}$ & $0.99^{d}$ & $0.82^{c}$ & $0.79^{b c}$ \\
\hline $20: 4 n-3$ & $1.18^{d}$ & $1.21^{\mathrm{d}}$ & $1.14^{\mathrm{d}}$ & $0.87^{a b}$ & $0.78^{a}$ & $0.78^{a}$ & $0.73^{a}$ & $0.98^{b c}$ & $1.10^{\mathrm{cd}}$ & $1.06^{\mathrm{cd}}$ \\
\hline $20: 4 n-6(A R A)$ & $2.08^{\mathrm{ab}}$ & $2.27^{\mathrm{bc}}$ & $2.66^{d}$ & $2.47^{\mathrm{cd}}$ & $2.13^{\mathrm{ab}}$ & $1.95^{\mathrm{a}}$ & $1.95^{a}$ & $4.73^{e}$ & 5.949 & $5.51^{f}$ \\
\hline $20: 5 n-3$ (EPA) & $10.00^{a}$ & $11.41^{\mathrm{a}}$ & $13.51^{b}$ & $23.99^{d}$ & $22.37^{\mathrm{cd}}$ & $22.45^{\mathrm{cd}}$ & $21.64^{c}$ & $27.59^{e}$ & $29.77^{f}$ & $28.46^{e f}$ \\
\hline $22: 5 n-3$ & $0.53^{a}$ & $0.69^{a}$ & $0.51^{\mathrm{a}}$ & $1.83^{c}$ & $1.38^{\mathrm{bc}}$ & $1.38^{\mathrm{bc}}$ & $1.37^{b}$ & $4.45^{d}$ & $6.56^{\mathrm{e}}$ & $6.07^{\mathrm{de}}$ \\
\hline $22: 6 n-3(D H A)$ & $4.68^{a}$ & $4.94^{a}$ & $5.12^{\mathrm{a}}$ & $11.96^{c}$ & $8.65^{\mathrm{bc}}$ & $8.86^{b c}$ & $8.46^{b}$ & $17.04^{d}$ & $20.59^{e}$ & $20.23^{e}$ \\
\hline Total FA & $103.88^{a}$ & $109.57^{a}$ & $139.94^{b}$ & $166.67^{d}$ & $157.96^{\mathrm{cd}}$ & $156.65^{\mathrm{cd}}$ & $152.23^{c}$ & $184.78^{\mathrm{e}}$ & $208.37^{9}$ & $200.91^{f}$ \\
\hline Saturates & $24.62^{a}$ & $25.90^{\mathrm{a}}$ & $35.65^{b}$ & $45.10^{d}$ & $42.89^{\mathrm{cd}}$ & $42.56^{\mathrm{cd}}$ & $41.28^{c}$ & $48.98^{e}$ & $56.68^{g}$ & $54.28^{f}$ \\
\hline Monounsaturates & $35.27^{a}$ & $37.03^{a}$ & $47.61^{b}$ & $58.56^{\mathrm{cd}}$ & $57.92^{\mathrm{cd}}$ & $57.04^{\mathrm{cd}}$ & $55.71^{\mathrm{c}}$ & $55.48^{c}$ & $60.14^{d}$ & $58.05^{d}$ \\
\hline Polyunsaturates & $43.99^{a}$ & $46.64^{a}$ & $56.68^{b}$ & $63.01^{c}$ & $57.15^{b}$ & $57.05^{b}$ & $55.23^{b}$ & $80.33^{d}$ & $91.55^{f}$ & $88.58^{e}$ \\
\hline n-3 HUFA & $16.40^{\mathrm{a}}$ & $18.25^{\mathrm{ab}}$ & $20.29^{b}$ & $38.66^{d}$ & $33.18^{c}$ & $33.46^{c}$ & $32.20^{c}$ & $50.05^{e}$ & $58.03^{g}$ & $55.83^{f}$ \\
\hline$n-3$ & $29.11^{a}$ & $30.46^{a}$ & $35.01^{b}$ & $42.70^{c}$ & $36.99^{b}$ & $37.24^{b}$ & $35.85^{b}$ & $54.20^{d}$ & $62.05^{f}$ & $59.83^{e}$ \\
\hline$n-6$ & $14.88^{a}$ & $16.19^{b}$ & $21.68^{d}$ & $20.31^{c}$ & $20.16^{c}$ & $19.81^{c}$ & $19.38^{c}$ & $26.13^{e}$ & $29.50^{g}$ & $28.75^{f}$ \\
\hline$n-3 / n-6$ & $1.96^{c}$ & $1.88^{\mathrm{bc}}$ & $1.61^{a}$ & $2.10^{d}$ & $1.83^{b}$ & $1.88^{b c}$ & $1.85^{\mathrm{b}}$ & $2.07^{d}$ & $2.10^{d}$ & $2.08^{d}$ \\
\hline DHA / EPA & $0.47^{\mathrm{cd}}$ & $0.43^{b c}$ & $0.38^{a}$ & $0.50^{d}$ & $0.39^{a b}$ & $0.39^{a b}$ & $0.39^{a b}$ & $0.62^{\mathrm{e}}$ & $0.69^{f}$ & $0.71^{f}$ \\
\hline DHA / ARA & $2.25^{\mathrm{a}}$ & $2.18^{a}$ & $1.92^{\mathrm{a}}$ & $4.86^{e}$ & $4.06^{\mathrm{bcd}}$ & $4.54^{\mathrm{de}}$ & $4.34^{\text {cde }}$ & $3.60^{\mathrm{b}}$ & $3.47^{b}$ & $3.67^{b c}$ \\
\hline Lipids (\%) & $16.33^{a}$ & $16.71^{\mathrm{a}}$ & $20.24^{b}$ & $23.50^{c}$ & $23.43^{c}$ & $24.01^{c}$ & $22.46^{c}$ & $26.94^{d}$ & $26.98^{d}$ & $27.34^{d}$ \\
\hline
\end{tabular}




\section{FIGURE CAPTIONS}

Fig. 1 Fatty acids content $\left(\mathrm{mg} \mathrm{g}^{-1}\right)$ in ongrownn Artemia submitted to LTE for 3,6 and 9 days (Days 9, 12, 15 and 18 of culture) and a subsequent STE on Prolon (D8), Red Pepper (D9) and Prolon + Red Pepper (D10).

Fig.2 Principal component analysis on fatty acids content in ongrownn (rectangles) and enriched (STE and LTE) adult Artemia: 2a and 2c: Scores plot (ongrowing and LTE and STE enrichment diets); $2 \mathrm{~b}$ and $2 \mathrm{~d}$ : Correlation loading plots (Fatty acids content). S: Saturates. M: Monounsaturates; P: Polyunsaturates. 

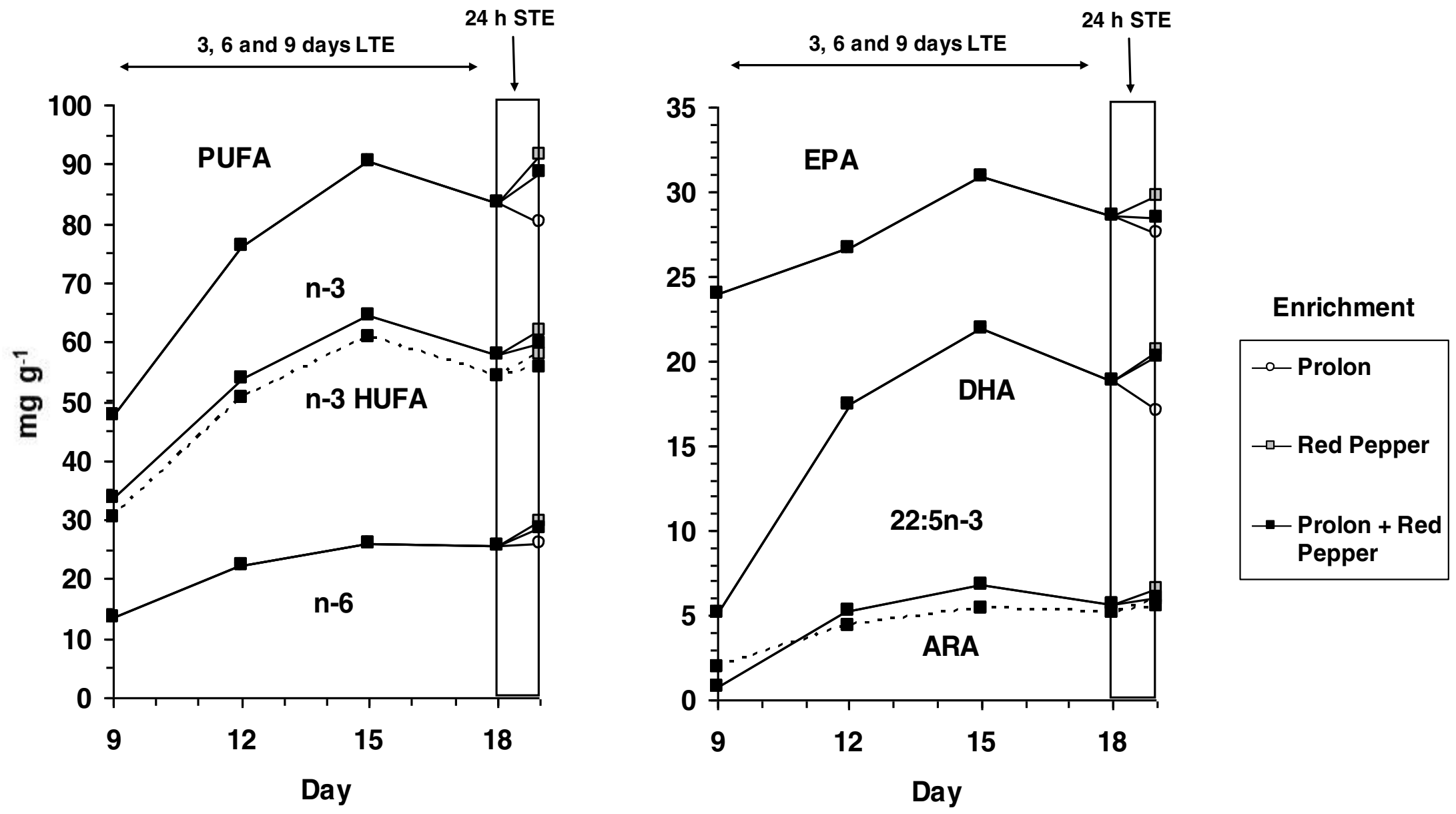

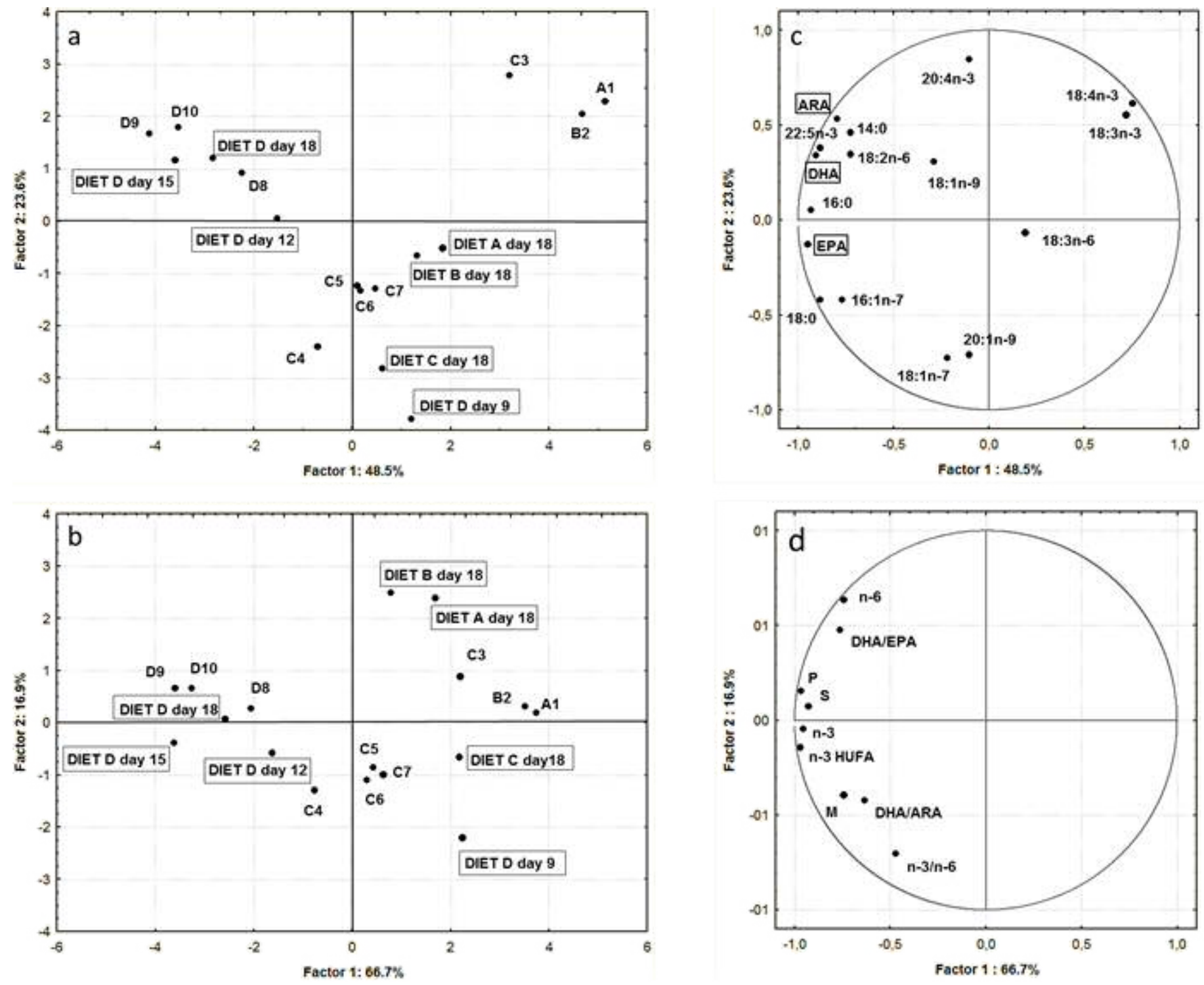